\title{
Perubahan Status Lifestyle Komsumtif Perempuan Dalam Menggunakan Online Shop
}

\author{
Sari Utami
}

Dosen Institute Agama Islam Negeri (IAIN) Bone

\begin{abstract}
The lifestyle of the Indonesian people has experienced the development of becoming more modern which is more practical and wants ease in all its activities. This study aims to explain and analyze changes in women's consumptive lifestyles in using online shops. This study uses descriptive qualitative research method, namely research that seeks to describe the object being examined and also dig up as much information as possible about the problem that is the topic of research based on facts that exist in the field, using key informants and informants as data sources.

The data presented uses primary data and secondary data through in-depth interviews, field observations, references relating to this research and internet data. Data analysis in this study refers to the interactive analysis model of Matthew B. Miles and A. Michael Huberman.

The results of this study that it can be concluded, Women in using online shops that have been active become increasingly consumptive in terms of shopping online to meet needs based on the desire to maintain appearance as a form of self-identity. The women used to buy items such as clothes, hijab, bags, shoes, cosmetics and accessories on an online shop on the basis of supporting the appearance to look beautiful and attractive, fulfilling a more trendy and current lifestyle, then buying the product because of the appearance of judgment that good products or high-priced products will create high self-esteem. They say that products that are purchased online all this time are their main need to maintain their appearance. But in reality unwittingly tends to be excessive and is an elaboration of understanding the theory of consumptive behavior.
\end{abstract}

Keywords : Consumptive, Internet, Lifestyle, Online Shop, Women.

\section{Pendahuluan}

Internet telah menjadi alternatif dalam melakukan aktivitas pembelian produk dan jasa. Lifestylemasyarakat Indonesia telah mengalami perkembangan menjadi semakin modern yang lebih praktis dan menginginkan kemudahan dalam segala aktivitasnya. Pesatnya pertumbuhan

pengguna internet di Indonesia memicu pertumbuhan e-commerce. E-commerce atau perdagangan elektronik merupakan proses pemasaran dan penjualan barang dan atau jasa melalui media internet. Pemanfaatan layanan pembelian melalui internet saling menguntungkan, baik bagi pelaku usaha maupun oleh konsumen online. Pelaku usaha berharap dengan menggunakan fasilitas penjualan online, konsumen dapat lebih mudah memilih dan memesan produk mana yang diinginkan, konsumen memperoleh informasi lebih lengkap sebelum memutuskan untuk melakukan pembelian, dan jangkauan penjualan menjadi lebih luas. Penjualan melalui internet 


\section{An-Nisa', Volume XI Nomor 2 Desember 2018}

juga dapat memberikan kenyamanan sehingga pelanggan tidak perlu bergelut dengan lalu lintas, tidak perlu mencari tempat parkir, dan berjalan dari toko ke toko. Risiko yang dimiliki oleh proses jual beli online adalah adanya celah bagi para penipu karena dalam prosesnya, penjual dan pembeli tidak bertatap muka dan pada umumnya pembeli harus melakukan pembayaran terlebih dahulu baru barang akan dikirim. ${ }^{57}$

Saat teknologi belum terlalu mendominasi beberapa aspek kehidupan, maka bentuk transaksi yang ditemukan pada saat itu juga relatif sederhana. Jual beli haruslah saling bertatap muka dan tawar menawar satu sama lain di suatu lokasi tertentu. Ketika teknologi internet berkembang dengan sangat pesat dan menghasilkan suatu model bisnis baru, maka suatu transaksi tidaklah harus menghadirkan dua orang pelakunya di suatu tempat tertentu. Kemajuan teknologi menghasilkan model pemasaran yang berbeda, sehingga sering ditemukan istilah terbaru yang berkaitan dengan e-business, e-commerce, e-marketing, affiliate marketing, online shop, online gallery, m-commerce dan lain sebagainya. Trend ini seiring dengan ekspektasi demand, yang selalu menginginkan kemudahan dalam mendapatkan apa yang mereka inginkan dan butuhkan. Banyak di antara masyarakat yang memiliki daya beli tinggi, enggan terjebak dalam rutinitas yang melelahkan, bergerak dari satu tempat ke tempat yang lain untuk membeli barang-barang yang mereka pilih. Di era teknologi sekarang ini, hanya dengan berselancar di internet beberapa detik, melalui e-commerce mereka akan bisa mendapatkan apa yang akan mereka mau. Dari sisi supply, potensi demand yang sangat besar dari aktifitas perdagangan online memunculkan para penjual dan produsen ,dadakan ${ }^{\text {ee }} .58$

Beberapa kalangan berbondong-bondong untuk menjadi penjual, pemasar dan atau produsen yang memasarkan produk mereka dengan cara online. Banyaknya aktifitas bisnis ini memunculkan para wirausahawan baru yang lambat laun cepat membesar, dikarenakan pengaruh penjualan online yang relatif cepat. Terbukti banyak wirausahawan baru, yang awalnya hanya mengandalkan penjualannya dengan cara online, kemudian secara bertahap bisa membangun toko offline-nya. Transaksi yang berkembang tidak secara nyata biasa terjadi memalui sistem elektronik seperti internet- yang biasa dikenali dengan e-commerce. Penjualan melalui $e$ -

57 Gadis Paramita dkk, Pengaruh Prior Online Purchase Experience Terhadap Trust Dan Online Repurchase Intention (Survey pada Pelanggan ZALORA Indonesia Melalui Website www.zalora.co.id), Fakultas Ilmu Administrasi Universitas Brawijaya Malang (JAB)|Jurnal Administrasi Bisnis,Vol. 16 No. 1 November 2014, h. 2-3

${ }^{58}$ Ika Yunia Fauzia, Pemanfaatan E-Commerce Dan M-Commerce dalam Bisnis di Kalangan Wirausahawan Perempuan, STIE Perbanas Surabaya, Jawa Timur, Indonesia, Journal of Business and Banking ISSN 20887841 Volume 5 Number 2 November 2015 - April, h. 237. 
commerce(electronic commerce) bisa mendongkrak omzet mereka, karena tidak memerlukan jam untuk berjualan, transaksi bisa dilakukan 24 jam nonstop, sehingga pelanggan lebih leluasa memilih berbagai macam produk dan membandingbandingkan harganya dari banyak vendor. $E$ commerce juga menghemat biaya yang harus dikeluarkan bagi para wirausahawan, dikarenakan biaya servis yang relatif murah karena tidak harus ada display barang, toko, dan lain sebagainya. ${ }^{59}$

Pengalaman (experience) dapat dikatakan sebagai sesuatu yang pernah dialami (dijalani, dirasai, ditanggung). Pembelian online konsumen sebelumnya memiliki korelasi yang kuat dengan niat pembelian online (Online Repurchase Intention). Kepercayaan merupakan konsep yang penting untuk berbagai bidang dalam bisnis dan kehidupan. ${ }^{60}$ Kepercayaan merupakan atribut penting yang harus diadopsi ke dalam aplikasi e-commerce. Kepercayaan menyiratkan keyakinan bahwa vendor website akan memberikan apa yang telah dijanjikan. Niat untuk membeli adalah jenis keputusan yang mempelajari mengapa pelanggan membeli merek tersebut. Niat pembelian ulang (Repurchase Intention) merupakan bentuk perwujudan dari hasil evaluasi seseorang terhadap sesuatu yang telah digunakan atau dikonsumsi sebelumnya. Niat pembelian online (Online Repurchase Intention) merupakan niat pembelian ulang konsumen terhadap suatu produk melalui online. ${ }^{61}$

Sesuai dengan berkembangnya e-commerce di Indonesia, saat ini mulai banyak pelaku usaha yang membuat toko online (online shop). Salah satu dari online shop yang ada di Indonesia. Indonesia yang merupakan pusat fashion di Indonesia dengan wawasan trend fashion global. Kelebihan sistem jual beli online seperti pada adalah konsumen (calon pembeli) dapat melihat produk barang atau jasa yang ditawarkan melalui gambar yang diposting oleh penjual tanpa harus bertatap muka dengan penjual. Transaksi pembayaran pada sistem jual beli online juga mudah. Konsumen dapat menggunakan kartu kredit, pembayaran langsung atau Cash On Delivery (COD), atau melakukan transfer uang pembayaran, baik melalui bank atau e-banking, yang ditujukan kepada rekening penjual. ${ }^{62}$

\footnotetext{
${ }^{59}$ Ibid., Ika Yunia Fauzia, Pemanfaatan E-Commerce Dan M-Commerce dalam Bisnis di Kalangan Wirausahawan Perempuan......................., h. 238.

${ }^{60}$ Ranganathan, C and Sanjeev Jha, Examining Online Purchase Intentions in B2C E-Commerce: Testing on Integrated Model. Information Resource Management Journal, Vol. 20, Issue 4, 2007, pp 48-64, h. 49.

${ }^{61}$ Mohmed, Abdalslam S. Imhmed, Nurdiana Binti Azizan, and Mohd. Zalisham Jali, The Impact of Trust and Past Experience on Intention to Purchase in E-Commerce. International Journal of Engineering Research and Development, Vol. 7, Issue 10, 2013, pp 28-35, h. 29.

${ }^{62}$ Ibid., Ika Yunia Fauzia, Pemanfaatan E-Commerce Dan M-Commerce Dalam Bisnis Di Kalangan Wirausahawan Perempuan. h. 239.
} 
Online Repurchase Intention konsumen pada lingkungan web shopping akan menentukan niat konsumen untuk melaksanakan perilaku pembelian tertentu melalui internet. ${ }^{63}$ Prior Online Purchase Experience dan Trust merupakan faktor yang mempengaruhi Online Repurchase Intention konsumen. Online Repurchase Intentionmerupakan situasi dimana konsumen ingin dan bermaksud untuk terlibat dalam sebuah transaksi online. Prior Online Purchase Experience dan Trust merupakan faktor yang mempengaruhi Online Repurchase Intention. ${ }^{64}$

Perkembangan dunia fashion didukung dengan perkembangan dunia teknologi dan internet yang telah membawa perubahan begitu besar terhadap manusia, dengan internet segala informasi dapat dicari dan ditelusuri dengan mudah sehingga dapat dimanfaatkan oleh seluruh pihak secara gratis dan mudah untuk menjalankan berbagai tujuan, salah satunya adalah melihat perkembangan tren fasion di Indonesia maupun di dunia melalui social media, website, ataupun berita- berita di internet. Hal ini dirasakan oleh masyarakat Indonesia terutama para generasi muda yang menjadikan gadget sebagai bagian dari kehidupan sehari-hari mereka, sebagian besar informasi mengenai tren fesyen didapatkan dari gadget yang mereka miliki, misalnya melihat tren fasion melalui media sosial) perbedaan pengalaman hidup yang dialami menandakan bahwa masing-masing generasi memiliki gaya hidup, pemahaman, ekspektasi, nilai, dan sikap yang berbeda. ${ }^{65}$

\section{Kajian Pustaka}

Shopping Lifestyle Menurut Zanblocki dan Kanter shopping lifestyle menunjukkan sebuah cara yang dipilih seseorang untuk mengalokasikan pendapatan, seperti dari segi dana untuk berbagai produk, serta alternatif tertentu. juga menjelaskan bahwa shopping lifestyle adalah gaya hidup seseorang untuk mengalokasikan waktu dan uang untuk berbagai kebutuhan dan keinginan yang ditentukan oleh faktor sikap terhadap merek, pengaruh iklan dan kepribadian. $^{66}$

\footnotetext{
${ }^{63}$ Salisbury, W.D., Pearson, R.A., Pearson, A.W., and Miller, D.W, Perceived Security and Worldwide Web Purchase Intention. Industrial Management and Data Systems, Vol 101 No 4, 2001, pp 165-177, h. 168.

${ }^{64}$ Pavlou, P. A, Consumer Acceptance of Electronic Commerce Integrating trust and Risk With The Technology Acceptance Model. International Journal of Electronic Commerce Research, Vol 7, No 3, 2003, pp 101-134, h. 104.

${ }^{65}$ Gilboa, S. \&.-Y, "Four generations of mall visitors in Israel: A study of mall activities, visiting patterns, and product purchased". Journal od Retailing and Consumer Services, 2010, pp. 501-511, h, 502.

${ }^{66}$ Japarianto, Edwin dan Sugiono, Sugiharto. "Pengaruh Shopping Lifestyle dan Fashion Involvement terhadap Impulse Buying Behavior Masyarakat High Income Surabaya" . J urnal M anajemen Pemasaran, Vol. 6, No.1, 2011, pp. 32- 41, h. 35 .
} 
Menurut Sproles dan Kendall terdapat 4 indikator berdasarkan teori Consumer Styles Inventory (CSI) Shopping Style Characteristics untuk menentukan karakteristik shopping lifestyle, yaitu: 1) Brand Consciousness, merupakan karakteritik konsumen ini cenderung mementingkan harga yang mahal, merek terkenal, dan percaya terhadap indikasi bahwa harga yang tinggi menunjukan kualitas yang baik. 2) Fashion Consciousness, merupakan karakteristik konsumen yang memiliki kesadaran dan keingintahuan terhadap fesyen dan gemar mencari tahu hal baru. Hal yang paling penting adalah mereka mencari hal yang bervariasi dan menyukai produk yang inovatif. 3) Shopping Conscious, merupakan karakteristik konsumen yang menjadikan berbelanja sebagai kesenangan dan sumber hiburan. 4) Impulsive Buying, merupakan karakteristik konsumen yang tidak peduli dengan jumlah uang yang mereka keluarkan, cenderung membeli barang tanpa direncanakan. Konsumen ini seringkali menyesali pembelian akhir. $^{67}$

Berbagai layanana sosial media dapat ditemukan di internet seperti RSS dan feed sindikasi web lain, blog, wiki, berbagi foto, video, podcast, sosial media, sosial bookmark, mashup, widget, microbloging, dan lain-lain. Aplikasi teknologi ini memfasilitasi interaksi dan kolaburasi. Pemilik konten dapat melakukan posting atau menambahkan konten, tapi pengguna lain memiliki kemampuan untuk memberikan kontribusi konten.

Platform sosial media dapat dikelompokkan ke dalam beberapa kategori besar, meskipun beberapa aplikasi mungkin masuk ke dalam lebih dari satu kategori tertentu tergantung pada bagaimana aplikasi tersebut digunakan. Secara kategori dapat di kelompokkan sebagai berikut : 68

a. Publikasi Web

Situs Web yang memungkinkan pengguna untuk mengirim atau mempublikasikan konten untuk menjangkau khalayak secara luas dan mendapatkan umpan balik. Contoh alat ini diantaranya adalah: Microblogging (Twitter, Plurk), Blogs (Wordpress, Blogger), Wiki (Wikispaces, PBWiki), Mashup (Google Maps, Popurls)

b. Jejaring Sosial

\footnotetext{
${ }^{67}$ Sproles, G. B., From perfectionism to dadaism: measuring consumers' decision-making styles. American council on consumer interest on Columbus, 1985, pp, 79-85. Dan Sproles, G.B., \& Kendall, E.L. .A Methodology for Profiling Consumers' Decision-Making Styles.Journal of Consumer Affairs, 20(2), 1986, pp. 267-279, h. 268.

68 Bambang Supradono dan Ayu Noviani Hanum, Peran Sosial Media Untuk Manajemen Hubungan Dengan Pelanggan Pada Layanan E-Commerce, Value Added, Vol. 7 , No.2, Maret 2011 - Agustus 2011 http://jurnal.unimus.ac.id, h. 35-36.
} 


\section{An-Nisa', Volume XI Nomor 2 Desember 2018}

Aplikasi ini memungkinkan pengguna untuk membangun koneksi dan berbagi informasi dengan pengguna lain. Sebuah layanan jaringan sosial pada dasarnya terdiri dari perwakilan dari tiap pengguna, hubungan sosial pengguna, dan berbagai layanan tambahan. Platform Umum jaringan sosial meliputi: Alat Sosial Media (Facebook, LinkedIn, Google), Sosial Bookmark (Delicious, Digg), Virtual Worlds (Second Life, OpenSim), Crowdsourcing / Sosial Voting (IdeaScale, Chaordix)

c. File Sharing

Penyimpanan Sebuah layanan hosting file atau penyedia penyimpanan file secara online yang dirancang khusus untuk menyimpan konten. Platform umum untuk file sharing / penyimpanan meliputi: Perpustakaan Foto (Flickr, Picasa), Video Sharing (YouTube, Vimeo), Audio Sharring (Podcast, Itunes), Penyimpanan (Google Documents, Drop.io., MySpace ), Manajemen Konten (SharePoint, Drupal)

Purchase intention adalah intensi seseorang untuk membeli merek tertentu yang mereka pilih sendiri setelah melalui berbagai evaluasi. Online Repurchase Intention merupakan situasi dimana konsumen berkeinginan dan berniat untuk kembali membuat transaksi online. Transaksi online dapat dianggap sebagai suatu kegiatan di mana proses pencarian informasi, transfer informasi, dan pembelian produk terjadi secara online. ${ }^{69}$ Beberapa faktor yang dapat mempengaruhi minat pembelian ulang (Repurchase Intention) konsumen. ${ }^{70}$

a. Faktor Psikologis

Meliputi pengalaman konsumen mengenai kejadian di masa lalu serta pengaruh sikap dan keyakinan konsumen terhadap suatu produk. Pengalaman konsumen dalam pembelian sebelumnya sangat berpengaruh dalam menentukan sikap dan pengambilan keputusan pembelian setelahnya.

b. Faktor Pribadi

Kepribadian dari seorang konsumen akan mempengaruhi persepsi dan pengambilan keputusan pembelian. Produsen perlu menciptakan situasi yang diharapkan oleh konsumen untuk menimbulkan minat pembelian ulang.

\footnotetext{
${ }^{69}$ Pavlou, P. A. 2003. Consumer Acceptance of Electronic Commerce Integrating trust and Risk With The Technology Acceptance Model. International Journal of Electronic Commerce Research, Vol 7, No 3, pp 101-134, h. 121.

${ }^{70}$ Kotler, Manajemen Pemasaran , Vol.1, Edisi 12, (Jakarta:Fakultas Ekonomi, 2009), h. UIKotler, P and Amstrong, G.. Principles of Marketing. 10th edition. (New Jersey: Prentice Hall,2004), h. 123.
} 
c. Faktor Sosial

Mencakup faktor kelompok anutan yang merupakan kelompok orang yang mempengaruhi sikap, pendapat, dan perilaku pembelian.

Teori Perilaku Konsumtif indikator perilaku konsumtif yaitu membeli produk karena iming-iming hadiah, membeli produk karena kemasannya menarik, membeli produk demi menjaga penampilan diri dan gengsi, membeli produk hanya sekedar menjaga simbol status, memakai produk karena unsur konformitas terhadap model yang mengiklankan, munculnya penilaian bahwa membeli produk dengan harga mahal akan menimbulkan rasa percaya diri yang tinggi, dan mencoba lebih dari dua produk sejenis (merek berbeda). ${ }^{71}$

Teori Persamaan Media Teori ini pertama kali dikenalkan oleh Byron Reeves dan Clifford Nass (professor jurusan komunikasi Universitas Stanford Amerika) dalam tulisannya The Media Equation: How People Treat Computers, Television, and New Media Like Real People and Places pada tahun 1996. Teori ini relatif sangat baru dalam dunia komunikasi massa. Media Equation Theory atau teori persamaan media ini ingin menjawab persoalan mengapa orang-orang secara tidak sadar dan bahkan secara otomatis merespon apa yang dikomunikasikan media seolah-olah (media itu) manusia.bahwa orang memperlakukan media komunikasi seperti memperlakukan manusia sebagai berikut: ${ }^{72}$

a. The Media Equation: Media = Real Life Dalam bukunya, The Media Equation, Reeves dan Nass menggagas bahwa kita menanggapi (response) media komunikasi seolah-olah media itu hidup. Implikasi praktis dari media equation ini adalah ketika kita menyalakan TV atau komputer kita, kita mengikuti aturan dari interpersonal interaction yang kita lalui selama hidup kita. Ini adalah human-media relations. Reeves dan Nass mengatakan bahwa media equation ini sifatnya sangat basic atau mendasar, jadi, "it applies to everyone, it applies often, and it is highly consequential".

b. Beyond Intuition that Protests: "Not Me, I Know A Picture Is Not A Person" The media equation jelas-jelas counterintuitive. Ketika kita menonton TV atau browsing internet, tidak seorangpun dari kita yang akan mengakui bahwa kita sebenarnya tengah merespons gambar-gambar di layar seolah-olah gambar-gambar itu nyata. Kita tahu bahwa yang ada di layar adalah gambar-gambar imajiner atau hanya representasi dari benda aslinya. Reeves dan Nass menyatakan sebaliknya. Keduanya menyatakan bahwa sebenarnya

\footnotetext{
${ }^{71}$ Sumartono. . Terperangkap dalam Iklan. (Bandung: Alfabeta, 2002), h.119.

Ibid, Sumartono. . Terperangkap dalam Iklan.............., h. 120-121. http://moza4learning.blogspot.com/2011/03/media-equation-theory_3435.html.
} 


\section{An-Nisa', Volume XI Nomor 2 Desember 2018}

orang merespons media secara sosial (socially) dan alami (naturally), meskipun mereka mereka tahu itu adalah hal yang tidak masuk akal untuk dilakukan, dan meskipun mereka tidak berpikir bahwa respons itu mencirikan diri mereka sendiri. Suatu kondisi di mana perilaku kita tidak dipengaruhi atau disesuaikan dengan situasi yang kita alami. Di satu sisi kita bilang "not me" yang merepresentasikan bahwa kita adalah makhluk independen dan kita sadar bahwa yang kita lihat adalah buatan. Di sisi lain, kita menanggapi gambar-gambar itu seperti kita tengah melakukan interaksi interpersonal dengan seseorang.

c. Otak Lama Dibodohi Teknologi Baru

Untuk menjelaskan alasan mengapa manusia menanggapi media secara sosial dan alami, Reeves dan Nass menggunakan teori langkah evolusi yang lambat. Menurut mereka, otak manusia terlibat hanya dalam aktivitas dan perilaku sosial, dan melihat semua objek yang dirasakan adalah benda nyata. Apapun yang kelihatan nyata, menjadi benar-benar nyata. Jadi sebenarnya kita belum beradaptasi dengan keberadaan media baru sehingga apapun yang kelihatan nyata, dipersonifikasikan oleh kita.

Teori yang dikemukakan oleh Reeves dan Nass ini tergolong dalam teori empiris (positivistik). Berdasarkan penggolongannya teori ini masuk dalam kategori teori empiris karena: ${ }^{73}$

1. Teori ini memprediksi bagaimana seseorang memperlakukan media (berdasarkan teori interpersonal) layaknya media itu adalah manusia

2. Teori ini menjelaskan bahwa pemirsa itu aktif

3. Teori ini relatif mudah dimengerti

4. Teori ini termasuk aliran positivis (generalisasi, satu kebenaran, perilaku bisa diprediksi, dan tidak melihat nilai-nilai yang dianut seseorang)

Jelas teori ini berkenaan sekali dengan penggunaan online shope saat ini, bahwa dengan media komunikasi seperti Instagram, facebook dan lain-lain yang merupakan aplikasi media sosial yang terfokuskan pada sebuah foto dan bahkan video yang memiliki berbagai informasi dan makna, kita dapat berinteraksi dengan media elektronik seperti smartphone seolah-olah smartphone ini adalah lawan bicara kita. Serta penggunaan nya yang saat ini sebagai media pemenuh kebutuhan untuk berbelanja secara praktis, cepat dan tepat waktu. Dalam hal ini

\footnotetext{
${ }^{73}$ Eva Melita Fitria, Dampak Online Shop Di Instagram Dalam Perubahan Gaya Hidup Konsumtif Perempuan Shopaholic Di Samarinda, eJournal Ilmu Komunikasi, Volume 3, Nomor 1, 2015: 117-128, h. 118-119.
} 
media-media seperti smartphone lah yang dapat digunakan untuk menunjang proses ini, media inilah yang menjadi lawan dalam komunikasi manusia. Karena itu dalam teori ini media pun disebutkan sebagai manusia karena mampu memberikan feedback langsung terhadap kita manusia yang mengkomunikasikannya.

Teori Konvergensi Media Konvergensi pada umumnya berarti persimpangan media lama dan baru. Seperti yang dikatakan oleh Henry Jenkins menyatakan bahwa konvergensi media adalah, "Aliran konten di platform beberapa media, kerja sama antara industri beberapa media dan perilaku migrasi khalayak media.” Konvergensi media tidak hanya pergeseran teknologi atau proses teknologi, namun juga termasuk pergeseran dalam paradigma industri, budaya, dan sosial yang mendorong konsumen untuk mencari informasi baru. Konvergensi media terjadi dengan melihat bagaimana individu berinteraksi dengan orang lain pada tingkat sosial dan menggunakan berbagai platform media untuk menciptakan pengalaman baru, bentuk-bentuk baru media dan konten yang menghubungkan kita secara sosial termasuk ketika para perempuan dalam penelitian ini menggunakan Instagram untuk berbelanja secara online, dan tidak hanya kepada konsumen lain, tetapi untuk para produsen perusahaan media. Konvergensi media merupakan proses yang terjadi sesuai dengan perkembangan budaya masyarakat. ${ }^{74}$

(Rakhmat:2005:205). Uses and Gratification menganggap individu sebagai makhluk suprarasional dan sangat selektif. Perhatiannya memang bukan lagi mengenai proses pengiriman pesan, namun pada proses penerimaan pesan. Melalui Uses and Gratification kita bisa melakukan penggambaran secara lebih holistik mengenai, bagaimana seorang individu menerima pesan yang dilakukannya melalui media. Lebih jauh lagi dari Melvin De Fleur, Uses and Gratification mencoba memetakan bagaimana motivasi dan kebutuhan membangun keinginan orang untuk berinteraksi dengan media. Dalam kedudukan ini, posisi orang ketika berhadapan dengan media bukanlah pihak yang pasif dan siap diinjeksi oleh media, tapi lebih jauh lagi bahwa, untuk berinteraksi dengan media pun, manusia mempunyai penyaring berupa kebutuhan dan motivasi. Dalam asumsinya, Uses and Gratification menyatakan bahwa : $:^{75}$

1. Khalayak dianggap aktif, artinya sebagian penting dari penggunaan media massa diasumsikan mempunyai tujuan

\footnotetext{
74 Ibid., Eva Melita Fitria, Dampak Online Shop Di Instagram Dalam Perubahan Gaya Hidup Konsumtif Perempuan..............., h. 119.

${ }^{75}$ Ling, Kwek Choon, Lau Teek Chai, and Tan Hoi Piew, The Effects of Shopping Orientations, Online Trust, Prior Online Purchase Experience toward Customers' Online Purchase Intention. International Business Research, Vol 3 No. 3 pp. 63-75, h. 70-71.
} 


\section{An-Nisa', Volume XI Nomor 2 Desember 2018}

2. Dalam proses komunikasi massa banyak inisiatif untuk mengaitkan pemuasan kebutuhan dengan pemilihan media terletak pada anggota khalayak

3. Media massa harus bersaing dengan sumber-sumber lain untuk memuaskan kebutuhannya. Bagaimana kebutuhan ini terpenuhi melalui konsumsi media amat bergantung pada perilaku khalayak yang bersangkutan

4. Tujuan pemilih media massa disimpulkan dari data yang diberikan anggota khalayak. Artinya orang dianggap cukup mengerti untuk melaporkan kepentingan dan motif pada situasi-situasi tertentu

5. Penilaian tentang arti kultural dari media massa sangat ditangguhkan sebelum diteliti lebih dahulu orientasi khalayak

\begin{tabular}{|c|c|}
\hline \multirow{6}{*}{ Uses and Gratification } & Faktor Sosial Psikologis Menimbulkan \\
\hline & Kebutuhan yang Melahirkan \\
\hline & Berbagai pola penghadapan media \\
\hline & Konsekuensi lain yang tidak diinginkan \\
\hline & $\begin{array}{l}\text { Harapan-harapan terhadap media atau } \\
\text { sumber lain }\end{array}$ \\
\hline & Menghasilkan gratifikasi kebutuhan \\
\hline \multirow{3}{*}{ Media Equation Theory } & Human with The Old Brain \\
\hline & Media \\
\hline & $\begin{array}{l}\text { Konsekuensi dari berinteraksi dengan media. } \\
\text { Termasuk mengikuti apa yang dilakukan } \\
\text { oleh media }\end{array}$ \\
\hline
\end{tabular}

Secara lebih spesifik bagaimana Uses and Gratification dan Media Equation Theory dapat dibedakan dengan memperhatikan kejadian berikut ini. penelitian terhadap penggunaan televisi oleh anak-anak. Dari penelitian ini, yang bersinggungan dengan Uses and Gratification, Brown memperlihatkan pentingnya media itu dalam sifatnya yang multi fungsional dan kemampuannya memberikan kepuasan yang bervariasai kepada sebagian besar anak-anak, seperti memberi penjelasan tentang bagaimana orang hidup di dunia dan memberikan bahan diskusi di antara anak-anak tersebut. Televisi bertindak sebagai medium yang memberikan referensi kepada anak-anak mengenai apa yang harus mereka lakukan dan apa yang tidak. 


\section{An-Nisa', Volume XI Nomor 2 Desember 2018}

Sedangkan dalam pandangan Media Equation Theory, televisi dalam kejadian ini bertindak sebagai komunikator, dimana anak-anak adalah komunikannya. Televisi yang berbicara dan anak-anak menjadi penerima pesannya. Ibarat orang, televisi yang menyuruh anak-anak untuk melakukan sesuatu. $^{76}$

Gaya Hidup Konsumtif Gaya hidup konsumtif mempunyai gambaran yang bermacammacam. Gaya hidup konsumtif merupakan suatu tindakan menggunakan suatu produk secara tidak tuntas. Artinya belum habis suatu produk dipakai, seseorang telah menggunakan produk lain dengan fungsi yang sama. Hal ini tentunya akan menghabiskan pengeluaran individu lebih banyak. Gaya hidup konsumtif adalah suatu perilaku yang ditandai oleh adanya kehidupan mewah dan berlebihan. ${ }^{77}$ Perilaku konsumtif juga ditunjukan dalam penggunaan segala hal yang dianggap paling mahal yang memberikan kepuasan dan kenyaman fisik sebesar-besarnya. Perilaku konsumtif juga menggambarkan adanya pola hidup manusia yang dikendalikan dan didorong oleh suatu keinginan untuk memenuhi hasrat kesenangan semata-mata.. ${ }^{78}$

Dampak Perilaku Konsumtif adalah suatu perubahan yang terjadi sebagai akibat suatu aktifitas dan aktifitas itu dapat dilakukan oleh manusia yang mengarah kepada perubahan dalam kehidupan manusia itu sendiri. Dengan demikian dampak adalah berarti nilai yang ditimbulkan oleh suatu peristiwa atau kejadian yang dialami oleh seseorang atau kelompok dalam proses pergaulannya atau dalam proses pekerjaannya. Dewasa ini berbagai online shop khususnya di Instagram semakin menjamur, berbagai produk yang ditawarkan kepada konsumen. Produkproduk ini bukan hanya barang yang dapat memuaskan kebutuhan seseorang melainkan memuaskan kesenangan seseorang.

Kebiasaan dan gaya hidup seseorang juga bisa berubah dalam jangka waktu yang relatif singkat menuju ke arah kehidupan mewah dan cenderung berlebihan, yang akhirnya menimbulkan perilaku konsumtif. Perilaku konsumtif ini kadang tidak melihat usia, jenis kelamin dan pekerjaan. Mereka bisa dari anakanak, remaja, dewasa bahkan orang tua, namun dari beberapa penelitian yang cenderung lebih berperilaku konsumtif khususnya pada kalangan perempuan, karena perempuan sangat gemar berbelanja. ${ }^{79}$

\footnotetext{
${ }^{76}$ Giantari, I GST Ayu KT. 2013. Pengaruh Pengalaman Terhadap Niat Beli via Online yang Dimediasi oleh Persepsi Kontrol Perilaku dan Kepercayaan. Tesis. Fakultas Ekonomi dan Bisnis Universitas Brawijaya. Tidak Diterbitkan.

${ }^{77}$ Sumartono,Terperangkap dalam Iklan. (Bandung: Alfabeta, 2002), h. 32.

${ }^{78}$ Subandy, Ectasy Gaya Hidup. (Jakarta: Grasindo, 1997), h. 45.

79 Ibid., Eva Melita Fitria, Dampak Online Shop Di Instagram Dalam Perubahan Gaya Hidup Konsumtif Perempuan. h. 121-122.
} 
Tabel Dimensi Perilaku Konsumtif

\begin{tabular}{|l|l|}
\hline \multicolumn{1}{|c|}{ Dimensi } & \multicolumn{1}{|c|}{ Indikator } \\
\hline Pemenuhan Keinginan & $\begin{array}{l}\text { Membeli produk hanya karena memenuhi } \\
\text { keinginan atau mencari kepuasan. }\end{array}$ \\
& $\begin{array}{l}\text { Membeli produk hanya karena ingin } \\
\text { mendapatkan sesuatu : iming-iming } \\
\text { hadiah, potongan harga besar atau murah }\end{array}$ \\
\hline Barang Diluar Jangkauan & $\begin{array}{l}\text { Membeli produk dengan harga yang diluar } \\
\text { batas kemampuan, berusaha keras membeli } \\
\text { produk diluar jangkauan dengan } \\
\text { menggunakan sebagian besar uang saku atau } \\
\text { simpanan, hingga meminjam uang. }\end{array}$ \\
\hline Barang menjadi tidak produktif & $\begin{array}{l}\text { Membeli produk tanpa memperdulikan } \\
\text { kebutuhan serta manfaat dan } \\
\text { kegunaannya. }\end{array}$ \\
& $\begin{array}{l}\text { Membeli barang atas dasar mencoba } \\
\text { produk, dengan membeli beberapa produk } \\
\text { (sejenis yang berbeda baik model, warna } \\
\text { maupun merk) }\end{array}$ \\
\hline Status & $\begin{array}{l}\text { Membeli produk karena menjaga } \\
\text { penampilan, perkembangan jaman dan gaya } \\
\text { hidup (tren) Membeli produk karena harga } \\
\text { diri }\end{array}$ \\
\hline
\end{tabular}

Sumber : Erich Fromm (1995) The Sane Society. New York : Reinhart

Perempuan Shopaholic

Konsumtivisme erat kaitannya dengan shopaholic. Shopaholic berasal dari kata shop yang artinya belanja dan aholic yang artinya suatu ketergantungan yang disadari ataupun tidak. Menurut Oxford Expans dikemukakan bahwa shopaholic adalah seseorang yang tidak mampu menahan keinginannya untuk berbelanja dan berbelanja sehingga menghabiskan begitu banyak waktu dan uang untuk berbelanja meskipun barang-barang yang dibelinya tidak selalu ia butuhkan.

Perlu diketahui bahwa tidak semua orang yang suka berbelanja atau pergi ke mall dapat dikatakan shopaholic. Seseorang dapat dikatakan mengalami shopaholic jika menunjukkan gejala-gejala sebagai berikut: a. Suka menghabiskan uang untuk membeli barang yang tidak dimiliki meskipun barang tersebut tidak selalu berguna bagi dirinya. b. Merasa puas pada saat dirinya dapat membeli apa saja yang diinginkannya, namun setelah selesai berbelanja maka dirinya merasa bersalah dan tertekan dengan apa yang telah dilakukannya. c. Pada saat merasa stress, maka akan selalu berbelanja untuk meredakan stresnya tersebut. d. Memiliki banyak barang-barang seperti baju, sepatu atau barang-barang elektronik, dll yang tidak terhitung 
jumlahnya, namun tidak pernah digunakan. e. Selalu tidak mampu mengontrol diri ketika berbelanja. Merasa terganggu dengan kebiasaan belanja yang dilakukannya.

\section{Metodologi Penelitian}

Penelitian ini menggunakan jenis penelitian deskriftif kualitatif, yaitu jenis penelitian yang memaparkan dan bertujuan memberikan gambaran serta penjelasan dari variabel yang diteliti dan juga menggali informasi sebanyak mungkin tentang persoalan yang menjadi topik penelitian. Penelitian ini menggunakan pendekatan fenomenologis. Penelitian dengan pendekatan fenomenologi berusaha untuk memahami makna dari berbagai peristiwa dan interaksi manusia didalam situasinya yang khusus. Bogdan \& Biklen, 1982 bahwa pendekatan fenomenologis menekankan pada berbagai aspek subjektif dari perilaku manusia supaya dapat memahami tentang bagaimana dan apa makna yang mereka bentuk dari berbagai peristiwa dalam kehidupan mereka sehari-hari. ${ }^{80}$ Fokus penelitian dalam sebuah penelitian kualitatif dimaksudkan untuk membatasi studi, sehingga dengan pembatasan studi tersebut akan mempermudah peneliti dalam mengolah data sehingga menjadi sebuah kesimpulan. Sesuai dengan permasalahan yang dibahas maka fokus penelitian yang ditetapkan, ialah perubahan status lifestyle comsumption perempuan dalam menggunakan online shop padaBidang Informasi dan Komunikasi, Bidang Ekonomi dan Industri, Bidang Sosial dan Budaya, Bidang Pendidikan. Dan Gaya hidup konsumtif perempuan yang diakibatkan oleh online shop, dalam mencakup berbagai dimensi yaitu Dimensi Pemenuhan Kebutuhan, Dimensi Barang diluar Jangakaun, Dimensi Barang menjadi tidak Produktif, Dimensi Status

Sumber data penelitian ini dibagi menjadi dua yaitu data primer dan data sekunder. Data Primer yaitu, data yang diperoleh melalui narasumber dengan cara melakukan wawancara secara langsung dan dipandu melalui pertanyaan pertanyaan yang sesuai dengan fokus penelitian. Narasumber didapatkan dengan cara atau teknik Sampling Purposif (Purposive Sampling), yaitu mencakup orang-orang yang diseleksi atas dasar kriteria-kriteria tertentu sesuai penelitian. Data Sekunder, yaitu data yang diperoleh dari sumber tidak langsung yang biasanya data dokumentasi, arsip-arsip, serta buku-buku ilmiah. Dalam penelitian ini penulis menggunakan buku-buku ilmiah, dokumen skripsi terdahulu, dan sumber-sumber lainnya seperti beberapa situs atau halaman website dari internet guna mendukung penelitian ini. Metode analisis data yang digunakan dalam penelitian ini adalah metode kualitatif deskriftif, yaitu mendeskripsikan serta menganalisis data yang telah diperoleh dan selanjutnya dijabarkan dalam bentuk penjelasan

\footnotetext{
${ }^{80}$ Sutopo, HB,Metodologi Penelitian Kualitatif. (Surakarta : UNS Press, 2002), h. 27.
} 


\section{An-Nisa', Volume XI Nomor 2 Desember 2018}

sebenarnya. Dengan menggunakan analisis data kualitatif model Interaktif, berdasarkan pendapat Miles dan Huberman, model analisis data ini dimulai dari alur kegiatan yang terjadi bersama dan saling terkait satu sama lain.

\section{Hasil Penelitian}

Dalam memenuhi kebutuhannya, perempuan melakukan kegiatan berbelanja, dalam penelitian ini dilakukan dengan berbelanja secara online pada online shop di Instagram. Online shop sendiri merupakan toko yang menjual berbagai barang - barang dan bahkan penawaran jasa secara online. Online shop menjadi sistem belanja yang sangat digemari karena juga merupakan sarana berbelanja modern, praktis dan mudah untuk memenuhi kebutuhan pokok hingga sekunder. Perempuan - perempuan yang merupakan informan dalam penelitian ini pun hasilnya dapat dikatakan sebagai perempuan shopaholic karena melihat hasil wawancara yang menyatakan bahwa para informan berbelanja online secara berlebihan dan tengah dalam perilaku konsumtif.

Dilihat dari hasil penelitian mengenai dampak media Instagram pada bidang ekonomi yang menimbulkan perilaku atau gaya hidup konsumtif maka pembahasan ini didasari dengan teori perilaku konsumtif. Teori perilaku konsumtif berbicara mengenai cara konsumen yang berlebihan dalam memenuhi kebutuhannya. Penjabarannya sesuai teori perilaku konsumtif ialah dimana konsumen atau individu atau para informan dalam penelitian ini yang membeli suatu barang karena adanya iming-iming hadiah, diskon dan harga murah, membeli produk karena tampilannya menarik atau karena foto barang yang disediakan oleh online shop di Instagram tersebut bagus dan menarik, membeli produk demi menjaga atau mendukung penampilan sesuai trend gaya hidup dan perkembangan zaman yang terbaru oleh penyedia informasi yaitu akun online shop di Instagram.

Konsumerisme demikian menunjukan identitas diri yang dicirikan atau disimbolkan oleh atribut-atribut tertentu. Shopping secara tidak sadar membentuk impian dan kesadaran semu para konsumer dan akhirnya melahirkan pola-pola konsumerisme yang tidak akan ada habisnya. Akhirnya berbelanja juga dianggap sebagai sebuah pekerjaan, sebuah aktivitas sosial dan suatu saat menjadi kompetisi untuk diri sendiri (memutuskan membeli atau tidak) juga terlebih untuk kompetisi pada teman dan anggota masyarakat yang lain (sebagai simbol status, gengsi, dan image manusia modern dan tidak ketinggalan zaman).

Dalam hasil penelitian dapat disimpulkan adanya perubahan gaya hidup perempuan ke arah yang konsumtif dalam menggunakan sebuah produk atau barang dan jasa. Hal ini didasari 
adanya keinginan yang tinggi baik dalam menunjang penampilan agar dapat memberikan simbol status agar terlihat lebih trend atau tidak ketinggalan zaman dimata orang lain. Mereka juga mengakui saat ini lebih senang berbelanja melalui online shop di Instagram, meskipun sebelumnya mereka pernah berbelanja online melalui media lain sepeti Facebook, Twitter, dan Blackberry Messengger namun tidak sesering seperti sekarang ini yang berbelanja online melalui Instagram secara berlebihan.

Hasil penelitian juga menjelaskan bahwa para perempuan biasa membeli barang - barang seperti baju, hijab, tas, sepatu, kosmetik dan aksesoris di online shop atas dasar demi mendukung penampilan agar terlihat cantik dan menarik, memenuhi gaya hidup yang lebih trend dan masa kini, lalu membeli produk tersebut karena munculnya penilaian bahwa produk yang bagus ataupun produk dengan harga mahal akan menimbulkan rasa percaya diri yang tinggi. Mereka mengatakan bahwa produk yang dibeli secara online selama ini merupakan kebutuhan utama mereka untuk menjaga penampilan mereka. Namun dalam kenyataannya tanpa disadari menjadi cenderung berlebihan dan merupakan penjabaran dari pemahaman teori perilaku konsumtif. Pembahasan hasil penelitian ini dapat disimpulkan secara singkat yaitu terjadinya perubahan perilaku atau gaya hidup konsumtif yang mengikuti perkembangan zaman, dimana para perempuan ini menggunakan sebuah media sosial Instagram untuk memenuhi kebutuhannya, membeli berbagai macam barang dengan jumlah yang berlebihan dan bukan atas dasar kebutuhan utama melainkan atas dasar pemenuhan keinginan, kepuasan, dan kesenangan semata untuk mendukung penampilan keseharian mereka.

\section{Kesimpulan}

Berdasarkan hasil penelitian, maka dapat ditarik kesimpulan mengenai hasil penelitian yaitu Instagram merupakan salah satu media baru yang memiliki tampilan menarik dan digemari bagi para penggunanya. Dan hal itu menjadi faktor bahwa Instagram telah berdampak pada bidang Ekonomi dimana penggunaan Instagram untuk berbelanja online secara berlebihan, dan terus - menerus dalam kurun waktu yang panjang telah berdampak negatif terhadap kalangan 


\section{An-Nisa', Volume XI Nomor 2 Desember 2018}

perempuan. Dan kecenderungan sebagai perempuan shopaholic mengakibatkan adanya dampak gaya hidup konsumtif.

Gaya hidup konsumtif merupakan kecenderungan perilaku individu untuk membeli atau mengkonsumsi barang - barang yang sebenarnya kurang diperlukan. Membeli suatu barang hanya karena mementingkan faktor keinginan, kepuasan, kesenangan dan mendukung penampilan sebagai wujud identitas diri, daripada kebutuhan sebenarnya. Apabila perilaku tersebut terus dilakukan tanpa ada kesadaran maka akan mengakibatkan pemborosan atau pengeluaran yang berlebihan.

Perempuan menjadi lebih konsumtif karena adanya keinginan diri untuk menunjang penampilan menjadi lebih menarik dengan mengikuti perkembangan gaya berpakaian masa kini. Hal ini merupakan wujud gaya hidup konsutif pada dimensi status yaitu membeli produk karena menjaga penampilan, mengikuti perkembangan zaman dan gaya hidup.

\section{Daftar Pustaka}

Yunia Fauzia, Ika. Pemanfaatan E-Commerce Dan M-Commerce dalam Bisnis di Kalangan Wirausahawan Perempuan, STIE Perbanas Surabaya, Jawa Timur, Indonesia, Journal of Business and Banking ISSN 2088-7841 Volume 5 Number 2 November 2015 - April.

Giantari, I GST Ayu KT. 2013. Pengaruh Pengalaman Terhadap Niat Beli via Online yang

Dimediasi oleh Persepsi Kontrol Perilaku dan Kepercayaan. Tesis. Fakultas Ekonomi dan Bisnis Universitas Brawijaya. Tidak Diterbitkan.

Gilboa, S. \&.-Y, "Four generations of mall visitors in Israel: A study of mall activities, visiting patterns, and product purchased”. Journal od Retailing and Consumer Services, 2010, pp. 501-511.

Japarianto, Edwin dan Sugiono, Sugiharto. "Pengaruh Shopping Lifestyle dan Fashion Involvement terhadap Impulse Buying Behavior Masyarakat High Income Surabaya". Jurnal Manajemen Pemasaran, Vol. 6, No.1, 2011, pp. 32- 41.

Kotler, Manajemen Pemasaran, Vol.1, Edisi 12, (Jakarta:Fakultas Ekonomi, 2009),

UIKotler, P and Amstrong, G.. Principles of Marketing. 10th edition. (New Jersey: Prentice Hall,2004). 
Ling, Kwek Choon, Lau Teek Chai, and Tan Hoi Piew.. The Effects of Shopping Orientations, Online Trust, Prior Online Purchase Experience toward Customers' Online Purchase Intention. International Business Research, Vol 3 No. 3, 2010, pp. 6375.

Melita Fitria, Eva. Dampak Online Shop Di Instagram Dalam Perubahan Gaya Hidup Konsumtif Perempuan Shopaholic Di Samarinda, eJournal Ilmu Komunikasi, Volume 3, Nomor 1, 2015: pp. 117-128.

Mohmed, Abdalslam S. Imhmed, Nurdiana Binti Azizan, and Mohd. Zalisham Jali, The Impact of Trust and Past Experience on Intention to Purchase in E-Commerce. International Journal of Engineering Research and Development, Vol. 7, Issue 10, 2013, pp 28-35.

Pavlou, P. A, Consumer Acceptance of Electronic Commerce Integrating trust and Risk With The Technology Acceptance Model. International Journal of Electronic Commerce Research, Vol 7, No 3, 2003, pp 101-134.

Paramita, Gadis., Parastanti Srikandi, Kumadji Kadarisman Hidayat, Pengaruh Prior Online Purchase Experience Terhadap Trust Dan Online Repurchase Intention (Survey pada Pelanggan ZALORA Indonesia Melalui Website www.zalora.co.id), Fakultas Ilmu Administrasi Universitas Brawijaya Malang (JAB)|Jurnal Administrasi Bisnis, Vol. 16 No. 1 November 2014.

Ranganathan, C and Sanjeev Jha, Examining Online Purchase Intentions in B2C E-Commerce: Testing on Integrated Model. Information Resource Management Journal, Vol. 20, Issue 4, 2007, pp 48-64.

Salisbury, W.D., Pearson, R.A., Pearson, A.W., and Miller, D.W, Perceived Security and Worldwide Web Purchase Intention. Industrial Management and Data Systems, Vol 101 No 4, 2001, pp 165-177.

Sproles, G. B., From perfectionism to dadaism: measuring consumers' decision-making styles. American council on consumer interest on Columbus, 1985, pp, 79-85.

Sproles, G.B., \& Kendall, E.L. .A Methodology for Profiling Consumers' Decision-Making Styles.Journal of Consumer Affairs, 20(2), 1986, pp. 267-279.

Subandy, Ectasy Gaya Hidup. (Jakarta: Grasindo, 1997).

Sumartono, Terperangkap dalam Iklan. (Bandung: Alfabeta, 2002).

Supradono. Bambang, dan Ayu Noviani Hanum, Peran Sosial Media Untuk Manajemen

Hubungan DenganPelanggan Pada Layanan E-Commerce, Value Added, Vol. 7 , No.2, Maret 2011 - Agustus 2011 http://jurnal.unimus.ac.id.

Susilowati, Pudji. Memilih Jurusan di Perguruann Tinggi. 2008, 
An-Nisa', Volume XI Nomor 2 Desember 2018

http://www.epsikologi.com/artikel/pendidikan/memilih-jurusan-di-perguruan-tinggi. (21 Januari 2014).

Sutopo, HB, Metodologi Penelitian Kualitatif. (Surakarta : UNS Press, 2002) 